\title{
Studies of Substrate Regulation in Fasting.
}

\author{
II. EFFECT OF INFUSION OF GLUCOSE INTO THE CAROTID \\ ARTERY UPON FASTING LIPOLYSIS IN THE BABOON
}

\author{
Martin J. Conway, Charles J. Goodner, Jon H. Werrbach, and \\ Charles C. Gale \\ From the Robert $H$. Williams Laboratory for Clinical Investigation, the \\ Departments of Medicine, the King County Harborview Hospital and the \\ University of Washington School of Medicine; and the Regional Primate \\ Research Center, and the Department of Physiology and Biophysics, \\ University of Washington, Seattle, Washington 98104
}

\begin{abstract}
A в S T R A C T The effect of glucose infusions on rates of lipolysis were studied in a group of chair-trained papio baboons that had been prepared for chronic intravenous and intracarotid infusion. All studies were carried out after a $24 \mathrm{hr}$ period of fasting and when the animals were fully awake. After a control interval of 1 $\mathrm{hr}$, a glucose infusion was begun either intravenously or intra-arterially. The infusion was continued at a constant rate for $2 \mathrm{hr}$ and then changed directly to the alternate route and continued an additional $2 \mathrm{hr}$. Blood samples were collected at 30 -min intervals for glucose, free fatty acid (FFA), glycerol, insulin, and in some studies, growth hormone (GH) determination. When glucose doses less than $0.5 \mathrm{mg} / \mathrm{kg}$ per min were used, no change in the products of lipolysis was noted during either venous or carotid administration, and glucose and insulin levels remained stable or fell gradually. With doses of glucose between 0.5 and $0.6 \mathrm{mg} / \mathrm{kg}$ per min, a greater fall in both FFA and glycerol was noted during carotid administration. No definite changes in plasma glucose or insulin levels were noted during either infu-
\end{abstract}

Portions of this work have been published in 1968. Clin. Res. 16: 158. (Abstr.) For complete data of Tables, order NAPS Document 00378 from ASIS National Auxiliary Publications Service, c/o CCM Information Sciences, Inc., 22 West 34th St., New York 10001, remitting $\$ 1.00$ for microfiche or $\$ 3.00$ for photocopies.

This work was performed by Dr. Conway under the tenure of a U. S. Public Health Service Research Fellowship AM 33, 182 and by Dr. Goodner under a Lederle Medical Faculty Award.

Received for publication 24 August 1968 and in revised form 31 March 1969. sion period. These changes in lipolysis were noted regardless of the sequence of infusion, and a similar differential suppression of FFA was noted during a $24 \mathrm{hr}$ period of carotid glucose administration. When doses of glucose larger than $0.6 \mathrm{mg} / \mathrm{kg}$ per min were used, inhibition of lipolysis was noted during both phases of infusion. No definite change in GH levels was noted during the periods of fasting, and the levels of the hormone did not appear to be related to changes in glucose, insulin, or FFA levels.

These data provide additional evidence for the presence in the central nervous system of a glucose-sensitive center which alters lipolytic rates independently of insulin and $\mathrm{GH}$, probably by altering sympathetic tone to adipose tissue.

\section{INTRODUCTION}

During periods of fasting, the provision of glucose and free fatty acids (FFA) as energy substrates in the mammalian organism appears to be under the control of several mechanisms, including neural, hormonal, and intracellular factors. In general, the plasma concentrations of glucose and FFA bear an inverse relationship to each other under the conditions of fasting, and it is well known that alterations in available glucose result in changes in FFA levels $(1,2)$. Although it is generally accepted that the increased lipolysis after lowering of plasma glucose results primarily from sympathetic discharge $(3,4)$, several mechanisms have been described through which an increase in available glucose may act to inhibit lipolysis (5). 


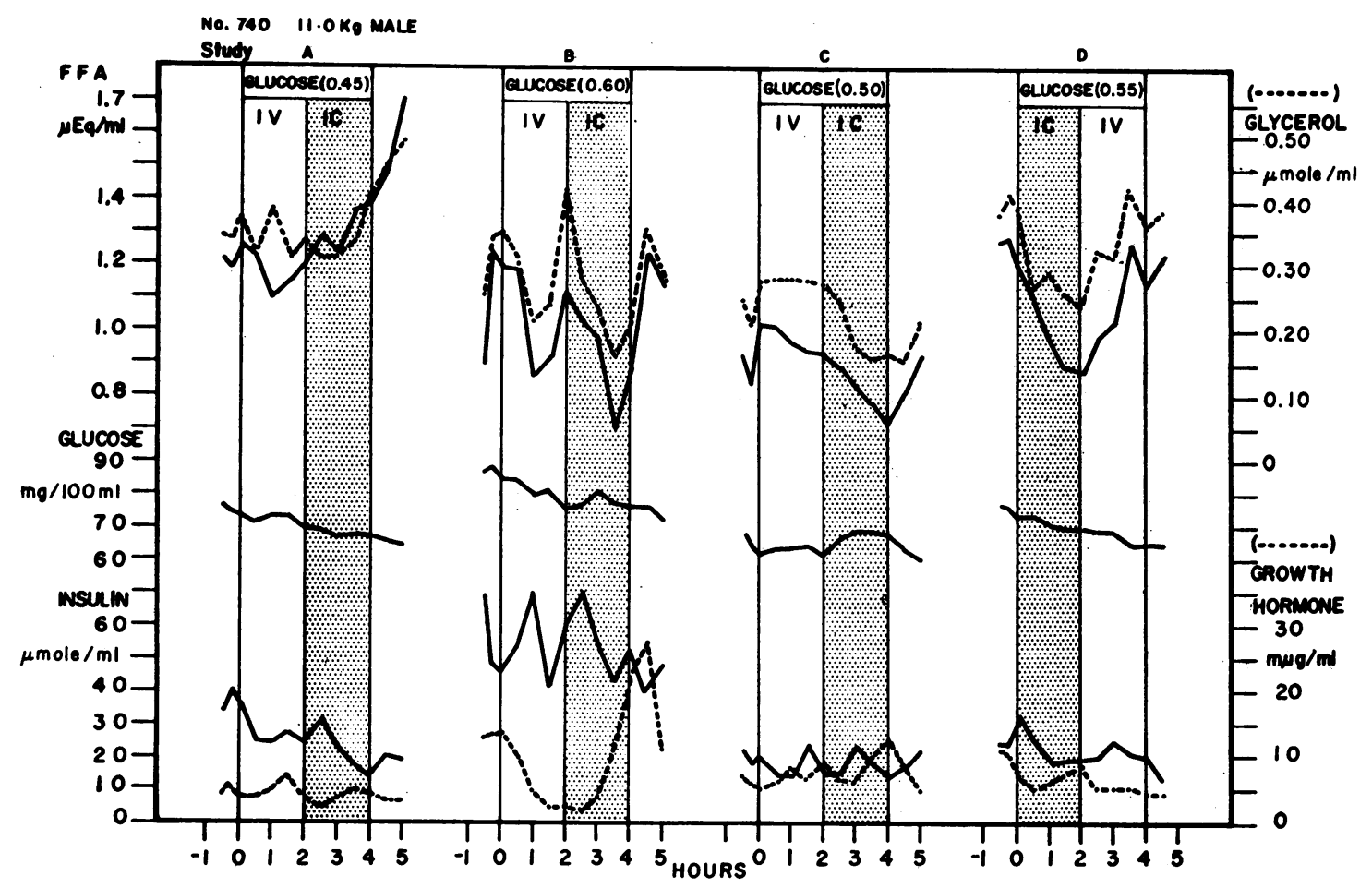

FIgURE 1 Four short-term infusion studies in a single baboon illustrating the effects of varying the rate of infusion of glucose into the internal carotid artery. The doses are given in parenthesis and are listed as milligrams of glucose per kilogram of body weight per minute. Infusions were delivered either intravenously into the right atrium (IV) or intracarotidly (IC). Venous blood samples were collected at 30-min intervals. In study $\mathrm{A}$, the dose of glucose did not elicit a fall in free fatty acids (FFA) or glycerol by either route. In study B, a higher dose elicited a fall in the products of lipolysis during both IV and IC infusions. An intermediate dose in studies C and D elicited a fall in FFA and glycerol only during IC infusion regardless of the sequence of infusion. In all of the studies, peripheral glucose, insulin, and growth hormone (GH) failed to change in a consistent pattern during infusion by either route.

The glucose fatty acid cycle proposed by Randle, Garland, Hales, and Newsholme (6) suggests that increased glucose may act directly at the level of the adipose cell to limit lipolytic rates. In addition, the increase in glucose may act to stimulate insulin secretion, in turn resulting in increased triglyceride synthesis in the adipose cell (7), as well as directly inhibiting lipolysis of preformed triglyceride (8). Glucose may also act at distant sites to limit the production of lipolytic hormones such as growth hormone (GH) (9) or glucagon $(10,11)$. In most studies, a large glucose stimulus has been utilized which probably resulted in mobilization of all of these antilipolytic mechanisms, and little attention has been paid to the means whereby these mechanisms are integrated to meet the changing needs of the organism. Previous observations in this laboratory (12, 13), utilizing glucose infusions which were insufficient to cause insulin secretion, led to the postulation of a glucose-sensitive center which alters lipolytic rates inde- pendently of insulin by changing sympathetic tone to adipose tissue. The present study provides additional support for this hypothesis and defines some operational characteristics of this control mechanism.

\section{METHODS}

Adult papio baboons ranging in weight from 8.3 to $13.0 \mathrm{~kg}$, which had been trained to chair living, were prepared for chronic arterial and venous infusion as follows. Under general anesthesia, the right common carotid artery, carotid sinus, and their branches were exposed and freed from adjacent structures. A Silastic catheter (Dow Corning Corporation, Midland, Mich.) with an internal diameter of 0.04 inches was passed through the external carotid or superior thryoidal artery, positioned, and fixed with ligatures so that the tip lay in the carotid sinus. All branches of the carotid sinus except the internal carotid and common carotid arteries were then ligated and divided, permitting infusion of materials through the catheter directly into the right internal carotid circulation. A second catheter was passed via the right internal jugular vein to about the level of the right atrium. To permit collection of venous blood samples 


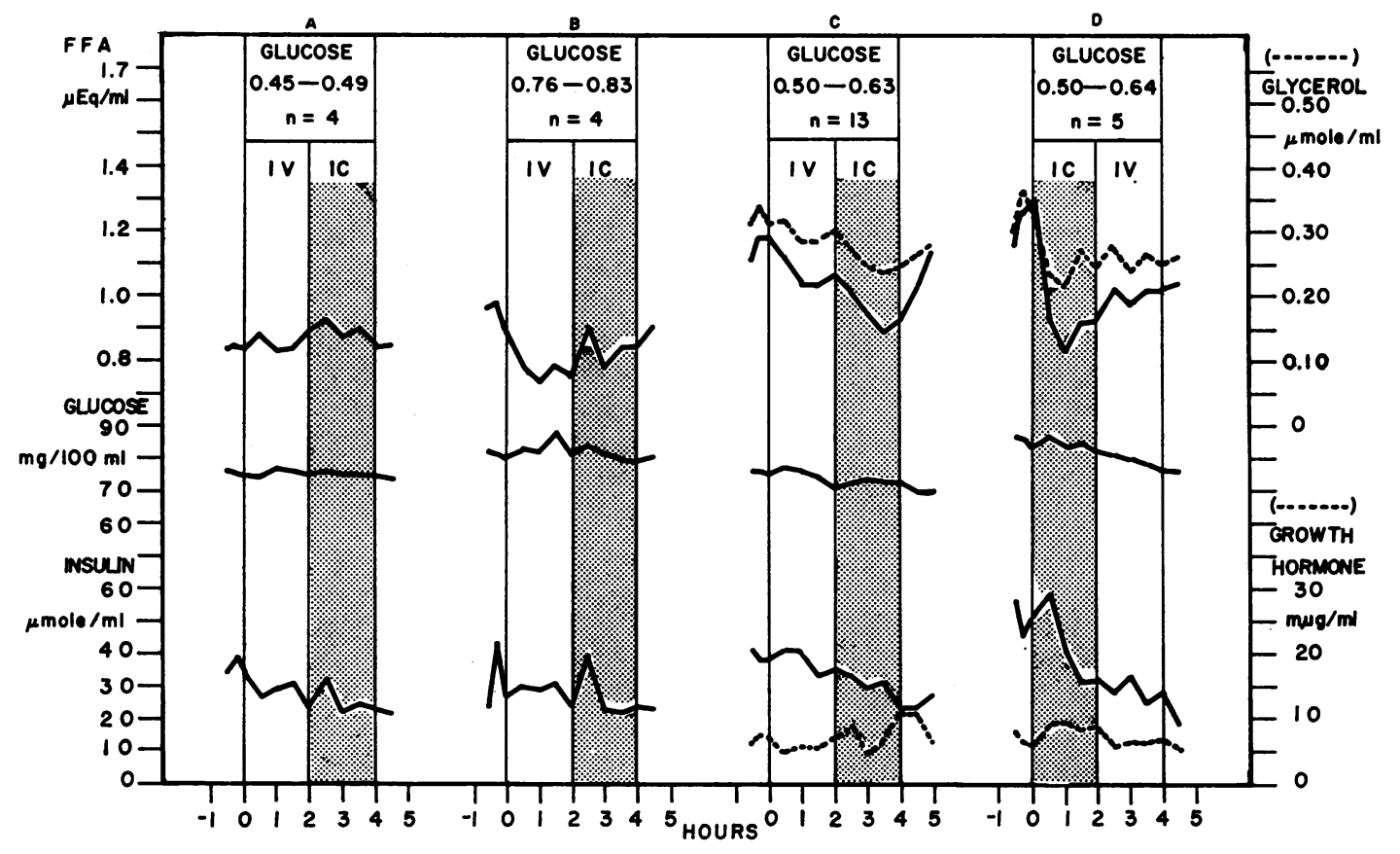

FIgURE 2 Mean values for FFA, glycerol, insulin, and GH during all short-term infusion studies grouped by dose range. The dose ranges are listed as milligrams/kilogram per minute. The number of experiments are given as $n$. Statistical analysis of changes during the infusion periods for protocols $\mathrm{C}$ and $\mathrm{D}$ are presented in Table V. The effects of glucose infused via the carotid artery (IC) upon FFA and glycerol were significantly greater than during intravenous infusion (IV).

during periods of venous infusion, double-lumen venous catheters were constructed by inserting polyethylene tubing (PE030) through a rubber-capped side arm in a larger Silastic catheter which had an internal diameter of 0.080 inches. The tubing was advanced within the catheter until its tip was approximately $1 \mathrm{~cm}$ from the end, inside the larger catheter, thereby permitting infusion via the internal catheter and blood sampling through the larger outer catheter. After placement of catheters in their respective blood vessels, the free ends were passed via a subcutaneous tunnel out through a scalp incision. Venous catheters were kept patent by simple gravity drip apparatus (Travenol microdrip); arterial catheter patency was maintained by means of a Sigmamotor infusion pump (Sigmamotor, Inc., Middlepor, N. Y.). The internal polyethylene venous catheter was filled with heparin during intervals between experiments. Infusions were commercially prepared intravenous saline solutions (Travenol) to which heparin, 50 $\mathrm{mg} / \mathrm{liter}$, was added, and infusion rates were adjusted to deliver a combined arterial and venous volume of $200 \mathrm{ml} / 24$

\footnotetext{
${ }^{1}$ Initially, maintenance of catheters was attempted without heparin, but because of clot formation in and about the catheters and problems of cerebrovascular accidents due to emboli, it was necessary to keep the animals chronically anticoagulated. In all cases, the dose of heparin per $24 \mathrm{hr}$ was $12 \mathrm{mg}$ or less. Because of the potential difficulties with stimulation of the lipoprotein lipase system, its activity was measured by the method of Fredrickson, Ono, and Davis
}

hr containing $10 \mathrm{mg}$ of heparin. ${ }^{1}$ Postoperative arteriograms were carried out in several animals to assure patency of the internal carotid circulation. After a 7-day postoperative recovery period, a series of glucose infusion studies were carried out in each animal. Infusion solutions were prepared by diluting an isotonic glucose solution ( $5 \%$ in water) with saline to obtain an isosmotic solution of desired glucose concentration. All studies were done after a 24-hr period of fasting, and all animals were fully awake during the study period. Studies were done in the following manner: after a control interval of $1 \mathrm{hr}$, a glucose solution was infused either intravenously or intra-arterially at a constant rate of $0.3 \mathrm{ml} / \mathrm{min}$ for a period of $2 \mathrm{hr}$ and then changed immediately to the alternate route and continued at the same rate for 2 more $\mathrm{hr}$. Infusions were given at $0.3 \mathrm{ml} / \mathrm{min}$ at all times into both catheters, both solutions being identical, containing heparin, and differing only by the glucose. During the control period and for a 1-hr recovery period after the end of glucose infusion, saline was infused at a rate of 0.3 $\mathrm{ml} / \mathrm{min}$ both intravenously and intracarotidly. In a number of animals a series of studies were done to determine the effect of different concentrations of glucose in the same animal or of different routes of administration for longer

(14) in eight of the animals after 7-10 days of heparin administration. While normal values are not available in the baboon, all but one animal had less than $0.03 \mathrm{U}$ of enzyme activity per $\mathrm{ml}$, which is within the normal fasting range in nonheparinized humans. 
TABLE I

Short-Term Infusion Studies: Dose of

\begin{tabular}{|c|c|c|c|c|c|c|c|}
\hline \multirow[b]{2}{*}{ Time in minutes. } & & & \multicolumn{3}{|c|}{ Saline control } & \multicolumn{2}{|c|}{$\begin{array}{l}\text { Intravenous glucose } \\
\text { infusion }\end{array}$} \\
\hline & $\ldots$ & $\ldots \ldots$ & -30 & -15 & 0 & 30 & 60 \\
\hline \multirow{11}{*}{$\begin{array}{l}\text { Four animals, } \\
0.45-0.49 \\
\mathrm{mg} / \mathrm{kg} \text { per } \min \S\end{array}$} & Mean (4)* & Gluf & 77 & 75 & 75 & 75 & 77 \\
\hline & $\begin{array}{l}\text { Range } \\
\mathrm{SE}\end{array}$ & & $\begin{array}{c}68-85 \\
3\end{array}$ & $\begin{array}{c}69-85 \\
3\end{array}$ & $\begin{array}{c}71-84 \\
3\end{array}$ & $\begin{array}{c}71-85 \\
3\end{array}$ & $\begin{array}{c}70-88 \\
3\end{array}$ \\
\hline & Mean (4) & FFA & 0.94 & 0.95 & 0.94 & 0.99 & 0.93 \\
\hline & Range & & $0.73-1.21$ & $0.66-1.18$ & $0.70-1.27$ & $0.69-1.27$ & $0.62-1.24$ \\
\hline & SE & & 0.09 & 0.11 & 0.12 & 0.13 & 0.11 \\
\hline & Mean (4) & Gly & 0.26 & 0.30 & 0.28 & 0.24 & 0.26 \\
\hline & Range & & $0.21-0.34$ & $0.22-0.34$ & $0.18-0.37$ & $0.13-0.32$ & $0.14-0.38$ \\
\hline & SE & & 0.03 & 0.03 & 0.04 & 0.04 & 0.05 \\
\hline & Mean (4) & IRI & 34 & 39 & 34 & 26 & 29 \\
\hline & Range & & $25-43$ & $34-43$ & $14-44$ & $20-36$ & $22-37$ \\
\hline & $\mathrm{SE}$ & & 4 & 2 & 6 & 3 & 3 \\
\hline \multirow{4}{*}{$\begin{array}{l}\text { Animal } 437, \text { study } \\
2,0.48 \mathrm{mg} / \mathrm{kg} \\
\text { per } \mathrm{min}\end{array}$} & & Glu & 81 & 83 & 85 & 83 & 90 \\
\hline & & FFA & 0.80 & 0.74 & 0.76 & 0.95 & 0.94 \\
\hline & & Gly & 0.20 & 0.18 & 0.20 & 0.30 & 0.26 \\
\hline & & IRI & 32 & 31 & 45 & 30 & 39 \\
\hline \multirow{4}{*}{$\begin{array}{l}\text { Animal } 696, \text { study } \\
3,0.48 \mathrm{mg} / \mathrm{kg} \\
\text { per min }\end{array}$} & & Glu & 71 & 71 & 76 & 73 & 71 \\
\hline & & FFA & 0.60 & 0.57 & 0.56 & 0.63 & 0.59 \\
\hline & & Gly & 0.20 & 0.16 & 0.15 & 0.12 & 0.14 \\
\hline & & IRI & 15 & 15 & 30 & 17 & 10 \\
\hline
\end{tabular}

* Number of samples for each time period.

$\ddagger$ Glucose $(\mathrm{Glu})(\mathrm{mg} / 100 \mathrm{ml})$, free fatty acids (FFA) $(\mu \mathrm{Eq} / \mathrm{ml})$, Glycerol (Gly) $(\mu \mathrm{M} / \mathrm{ml})$, Insulin (IRI) $(\mu \mathrm{U} / \mathrm{ml})$.

$\S$ Dose of glucose administered during infusion period.

periods. In all such serial studies, a period of at least $72 \mathrm{hr}$ was permitted between experiments for refeeding. During control, infusion, and recovery periods venous blood samples were collected at 30-min intervals for glucose, FFA, glycerol, and insulin determination. In several experiments, $\mathrm{GH}$ assays were also performed. In addition to the use of a "double lumen" venous catheter to avoid contamination of blood samples by infused glucose, infusions were stopped for $30 \mathrm{sec}$ before and during blood collection so that infusions were interrupted for approximately $1 \mathrm{~min}$ for each blood sample.

To assess the effects of a more prolonged infusion, two animals were studied during a 24 -hr period of glucose administration. The animals were first fasted for $20 \mathrm{hr}$, and a glucose infusion was then begun either intracarotidly or intravenously and continued at a constant rate of $0.3 \mathrm{ml} /$ min for the next $24 \mathrm{hr}$. For $1 \mathrm{hr}$ before and for a recovery period of $3 \mathrm{hr}$ after termination of glucose infusion, saline was infused both intravenously and intracarotidly at the same rate. After this study, the animals were refed, and after 1 wk the study was repeated in a similar fashion but utilizing the alternate route of infusion. In one animal, the carotid route was used initially; in the other the glucose was infused intravenously first. Venous blood samples were collected at $30 \mathrm{~min}$ intervals during the control period, the first $3 \mathrm{hr}$ of infusion, the last hour of infusion, and during the 3-hr recovery period for determination of glucose, FFA, insulin, and GH.

In all studies, blood samples were divided into a $6 \mathrm{ml}$ heparinized specimen from which the plasma was promptly separated and a $2 \mathrm{ml}$ specimen, which was permitted to clot for $2 \mathrm{hr}$ at room temperature, and the serum then separated. Both plasma and serum samples were frozen and stored at $-20^{\circ} \mathrm{C}$ until analysis. Plasma samples were analyzed in duplicate for glucose by the ferricyanide method on a Technicon Autoanalyzer; FFA were determined by a modification of the method of Dole and Meinertz (15) and plasma glycerol by a modification of Wieland's (16) method. Serum immunoreactive insulin was assayed by the double-antibody method of Morgan and Lazarow (17) using a pork standard. GH levels were determined by the method of Schalch and Parker (18) using a human GH standard. All samples from each study were assayed concurrently.

\section{RESULTS}

Short-term infusion studies were carried out to determine a dose of glucose which might cause a definite reduction in lipolysis when given into the carotid circulation but have little or no effect when administered intravenously. The results of a series of such studies done in a single animal are shown graphically in Fig. 1, and 


\begin{tabular}{|c|c|c|c|c|c|c|c|}
\hline \multicolumn{2}{|c|}{$\begin{array}{l}\text { Intravenous glucose } \\
\text { infusion }\end{array}$} & \multicolumn{4}{|c|}{ Intracarotid glucose infusion } & \multicolumn{2}{|c|}{ Recovery } \\
\hline 90 & 120 & 150 & 180 & 210 & 240 & 270 & 300 \\
\hline 76 & 75 & 77 & 76 & 76 & 75 & 73 & 74 \\
\hline $71-84$ & $67-85$ & $69-88$ & $66-81$ & $67-86$ & $67-84$ & $65-85$ & $64-84$ \\
\hline 3 & 4 & 4 & 3 & 4 & 4 & 4 & 7 \\
\hline 0.95 & 1.00 & 1.04 & 0.97 & 1.00 & 0.95 & 0.96 & 1.29 \\
\hline $0.81-1.14$ & $0.86-1.20$ & $0.89-1.28$ & $0.76-1.23$ & $0.75-1.36$ & $0.76-1.38$ & $0.71-1.49$ & $0.82-1.76$ \\
\hline 0.06 & 0.07 & 0.08 & 0.09 & 0.11 & 0.13 & 0.16 & 0.33 \\
\hline 0.25 & 0.30 & 0.26 & 0.25 & 0.22 & 0.23 & 0.24 & 0.32 \\
\hline $0.20-0.30$ & $0.20-0.42$ & $0.13-0.36$ & $0.18-0.32$ & $0.12-0.34$ & $0.14-0.40$ & $0.11-0.44$ & $0.16-0.48$ \\
\hline 0.02 & 0.04 & 0.04 & 0.03 & 0.04 & 0.05 & 0.06 & 0.11 \\
\hline 32 & 23 & 28 & 22 & 25 & 23 & 22 & 19 \\
\hline $24-45$ & $13-35$ & $18-36$ & $17-29$ & $13-36$ & $14-34$ & $14-30$ & $18-19$ \\
\hline 4 & 4 & 3 & 2 & 5 & 4 & 3 & 3 \\
\hline 91 & 85 & 87 & 82 & 81 & 81 & 79 & \\
\hline 0.88 & 0.89 & 0.82 & 0.79 & 0.90 & 0.97 & 0.81 & \\
\hline 0.22 & 0.29 & 0.20 & 0.20 & 0.18 & 0.28 & 0.28 & \\
\hline 45 & 25 & 35 & 25 & 31 & 36 & 23 & \\
\hline 71 & 74. & 76 & 74 & 75 & 76 & 74 & 74 \\
\hline 0.49 & 0.58 & 0.61 & 0.54 & 0.58 & 0.58 & 0.62 & 0.72 \\
\hline 0.12 & 0.14 & 0.15 & 0.14 & 0.14 & 0.13 & 0.13 & 0.16 \\
\hline 14 & 18 & 28 & 10 & 15 & 16 & 10 & 14 \\
\hline
\end{tabular}

the mean values for all studies are presented in Fig. 2. The individual data from these infusion studies are presented in Tables I-IV. The experiments have been subdivided for tabulation and graphic presentation by dose range of glucose infused. It was found that when glucose was infused at rates below $0.5 \mathrm{mg} / \mathrm{kg}$ per min, either intravenously or intra-arterially, no effect on lipolysis was noted (Table I, Fig. $2 \mathrm{~A}$ ). With doses greater than $0.64 \mathrm{mg} / \mathrm{kg}$ per min, FFA and glycerol fell during infusion of glucose by either route (Table IV, Fig. 2 B), while during infusion of glucose at rates between 0.5 and $0.64 \mathrm{mg} / \mathrm{kg}$ per min, a greater fall in FFA and glycerol was observed during intracarotid infusion than during intravenous infusion regardless of the sequence of infusions (Tables II and III, and Fig. 2C and D). Fig. 3 presents individual experiments in four animals infused with doses in this range and serves to illustrate the variability in the pattern of response among individual animals. In order to test the significance of changes during the infusion periods, a mean value for the data from each infusion period was calculated for each experiment. Means were derived for four periods; the control period $(C)$ with three samples, the intravenous $(I V)$ and intracarotid $(I C)$ infusion periods each with four samples, and the recovery $(R)$ period with two samples. Differences between means for infusion periods were calculated for each animal. Then the mean differences and their variance were calculated within experimental groups studied with the same sequence of infusions. For each of the two protocols $(C \rightarrow I V-I C-R$ and $C \rightarrow I C-I V-R)$, four differences were calculated, as illustrated in Table V. Paired $t$ tests were applied to each of the differences, and the results are summarized in Table V. The grand means for each infusion period are also listed on the left in Table V.

In experiments with the sequence, $\mathrm{C}-\mathrm{IV}-\mathrm{IC}-\mathrm{R}$, a significant fall in FFA but not glycerol occurred between the control and intravenous infusion periods. A significant further reduction in both FFA and glycerol occurred between the intravenous and intracarotid infusion periods. There was then a significant rise in FFA during the recovery period. When the sequence was reversed, so that the intracarotid infusion came immediately 
TABLE II

Short-Term Infusion Studies: Dose of Glucose

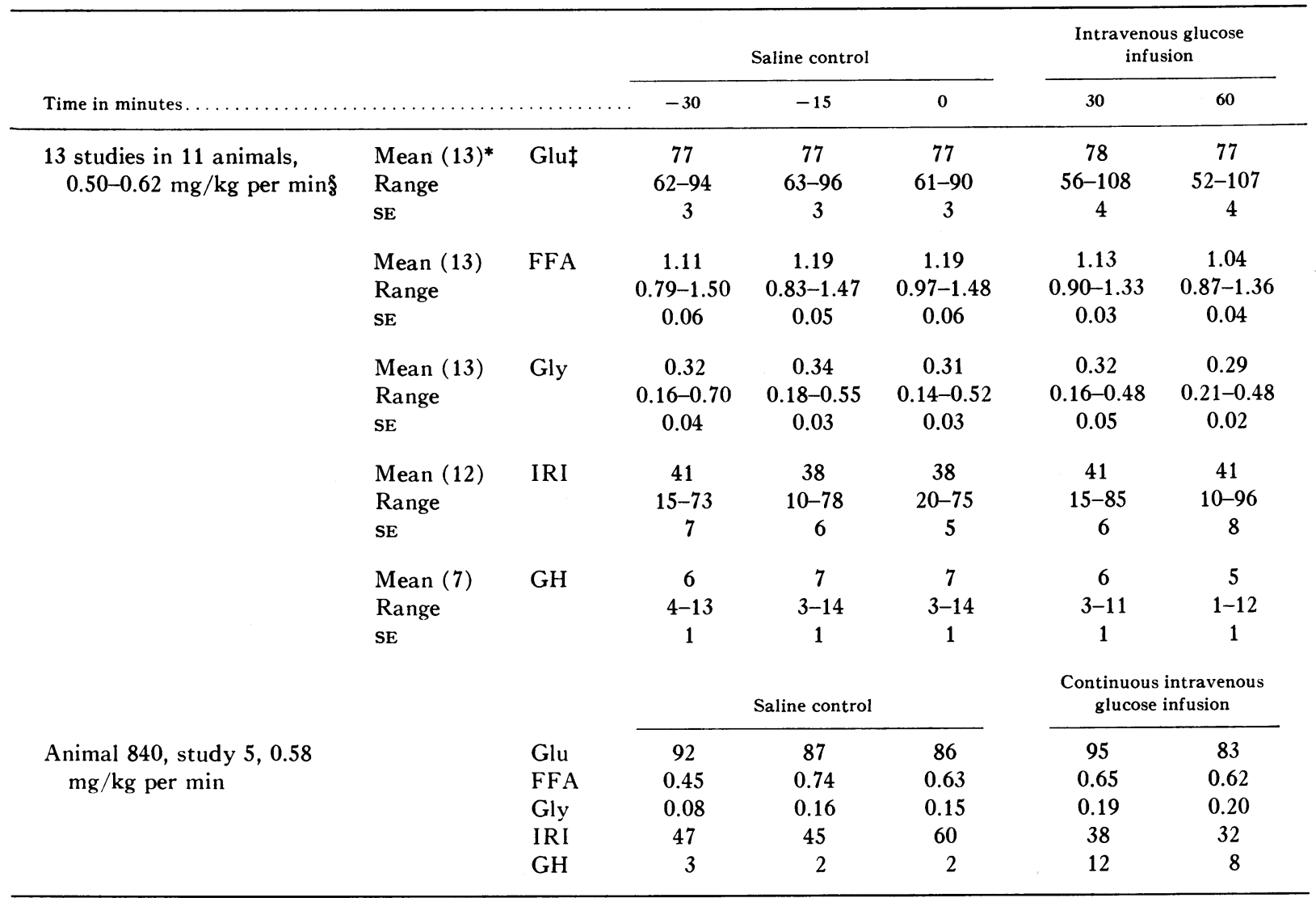

* Number of samples for each time period.

$\ddagger$ Glu $(\mathrm{mg} / 100 \mathrm{ml})$, FFA $(\mu \mathrm{Eq} / \mathrm{ml})$, Gly $(\mu$ moles $/ \mathrm{ml})$, IRI $(\mu \mathrm{U} / \mathrm{ml})$, growth hormone $(\mathrm{GH})(\mathrm{m} \mu \mathrm{g} / \mathrm{ml})$.

$\S$ Dose of glucose administered during infusion period.

after the control period, a significant fall in both FFA and glycerol occurred. These reductions in FFA and glycerol were significantly greater than the corresponding reductions in experiments in which the intravenous route came immediately after the control period $(P<$ $0.005)$. With the sequence $\mathrm{C}-\mathrm{IC}-\mathrm{IV}-\mathrm{R}, \mathrm{FFA}$ and glycerol did not fall further during the fourth period but in fact tended to rise, although the change was not significant. Glucose and insulin concentrations tended to fall throughout the experiment in both protocols.

During the short-term infusion studies, a rather striking change in behavior was noted in a majority of the animals during carotid glucose infusion. At the start of experiments, after a $24 \mathrm{hr}$ period of fasting, the animals were alert and usually actively moving about in the chairs; this behavior continued throughout the control and intravenous glucose infusion period. Within $30 \mathrm{~min}$ after the start of carotid glucose administration, how- ever, sedation was noted in 15 out of 18 experiments. This condition was characterized by a striking decrease in activity, drowsiness, and occasional brief periods of napping and usually continued until the glucose infusion was terminated. This behavior occurred during the intracarotid infusion regardless of the sequence of infusions.

In two animals, glucose was infused for $24 \mathrm{hr}$, as shown in Fig. 4. Baboon No. 546 received $10 \mathrm{~g}$, and baboon No. 701 received $8 \mathrm{~g}$ of glucose in total over each of the two $24 \mathrm{hr}$ infusions periods. Relative suppression of FFA levels was noted during intracarotid infusion compared with infusion of the same dose intravenously. In animal No. 546, FFA and glycerol rose during the venous infusion experiment as would be expected with continued fasting. During carotid infusion under identical conditions, FFA and glycerol fell and remained depressed for the $24 \mathrm{hr}$ period. In animal No. 546, there was a sudden rise in FFA level associated 


\begin{tabular}{|c|c|c|c|c|c|c|c|}
\hline \multicolumn{2}{|c|}{$\begin{array}{l}\text { Intravenous glucose } \\
\text { infusion }\end{array}$} & \multicolumn{4}{|c|}{ Intracarotid glucose infusion } & \multicolumn{2}{|c|}{ Recovery } \\
\hline 90 & 120 & 150 & 180 & 210 & 240 & 270 & 300 \\
\hline 75 & 72 & 73 & 75 & 74 & 74 & 70 & 70 \\
\hline $57-94$ & $57-91$ & $55-90$ & $55-89$ & $53-90$ & $56-87$ & $58-85$ & $60-87$ \\
\hline 3 & 3 & 3 & 3 & 3 & 2 & 2 & 3 \\
\hline 1.04 & 1.07 & 1.02 & 0.96 & 0.90 & 0.94 & 1.03 & 1.14 \\
\hline $0.91-1.19$ & $0.84-1.27$ & $0.62-1.21$ & $0.79-1.09$ & $0.65-1.06$ & $0.71-1.17$ & $0.73-1.27$ & $0.97-1.35$ \\
\hline 0.03 & 0.04 & 0.04 & 0.03 & 0.04 & 0.04 & 0.05 & 0.04 \\
\hline 0.29 & 0.30 & 0.28 & 0.25 & 0.24 & 0.25 & 0.26 & 0.28 \\
\hline $0.18-0.42$ & $0.20-0.52$ & $0.14-0.60$ & $0.15-0.44$ & $0.12-0.37$ & $0.10-0.40$ & $0.11-0.42$ & $0.18-0.50$ \\
\hline 0.02 & 0.02 & 0.03 & 0.02 & 0.02 & 0.02 & 0.03 & 0.03 \\
\hline 33 & . 35 & 33 & 29 & 32 & 23 & 24 & 28 \\
\hline $15-66$ & $10-61$ & $10-74$ & $4-69$ & $18-43$ & $9-36$ & $5-40$ & $12-47$ \\
\hline 4 & 5 & 5 & 4 & 2 & 3 & 3 & 5 \\
\hline 5 & 7 & 8 & 5 & 6 & 11 & 11 & 6 \\
\hline $1-19$ & $1-15$ & $1-38$ & $1-9$ & $3-12$ & $2-23$ & $2-27$ & $2-11$ \\
\hline 2 & 2 & 5 & 1 & 1 & 2 & 3 & 1 \\
\hline \multicolumn{6}{|c|}{ Continuous intravenous glucose infusion } & \multicolumn{2}{|c|}{ Recovery } \\
\hline 82 & 81 & 90 & 77 & 81 & 81 & 78 & \\
\hline 0.71 & 0.90 & 0.83 & 0.92 & 0.94 & 0.93 & 0.88 & \\
\hline 0.24 & 0.20 & 0.22 & 0.16 & 0.22 & 0.20 & 0.19 & \\
\hline 40 & 35 & 34 & 34 & 28 & 29 & 38 & \\
\hline 5 & 5 & 8 & 9 & 6 & 5 & 3 & \\
\hline
\end{tabular}

with a fall in plasma glucose after carotid glucose infusion ended. In animal No. 701, there was a downward trend of FFA levels during venous infusion. However, there was a much more marked suppression of FFA levels during carotid infusion.

In all of the short-term studies in which $\mathrm{GH}$ levels were determined, no consistent pattern of response was noted (Fig. 2). In a few of the animals, brief abrupt elevations were noted during the course of experiments as illustrated by animal No. 740, study B in Fig. 1, and by animal Nos. 741, 743, and 280 in Fig. 3. In general, $\mathrm{GH}$ appeared to behave independently of glucose or FFA-glycerol levels and was apparently unrelated to the concentration of insulin as well. Similarly, during prolonged infusion studies conducted during a total fasting period of $48 \mathrm{hr}, \mathrm{GH}$ values remained quite low, ranging between 1 and $7.5 \mathrm{~m} \mu \mathrm{g} / \mathrm{ml}$, with no upward or downward trend during either carotid or venous glucose infusion.

\section{DISCUSSION}

In the present study, small doses of glucose administered directly into the cerebral circulation resulted in a fall in both glycerol and FFA, a finding indicating reduction in the rate of lipolysis in the adipose tissue cell during the period of glucose administration. Similar amounts of glucose administered intravenously had a lesser effect on lipolytic rates. These data provide evidence for the presence of a glucose-responsive center lying within the area supplied by the carotid circulation, which acts as a regulator of fat mobilization during periods of fasting. The differential effect of carotid versus venous infusion of glucose was also evident during prolonged infusions, a finding suggesting that the center is active 
TABLE III

Short-Term Infusion Studies: Dose of Glucose

\begin{tabular}{|c|c|c|c|c|c|c|c|}
\hline \multirow{2}{*}{ Time in minutes. . } & & & \multicolumn{3}{|c|}{ Saline control } & \multicolumn{2}{|c|}{$\begin{array}{l}\text { Intracarotid glucose } \\
\text { infusion }\end{array}$} \\
\hline & & & -30 & -15 & 0 & 30 & 60 \\
\hline \multirow{15}{*}{$\begin{array}{l}\text { Five animals, } \\
\quad 0.52-0.64 \\
\mathrm{mg} / \mathrm{kg} \text { per } \min \S\end{array}$} & Mean $(5)^{*}$ & Gluł & 87 & 86 & 83 & 87 & 84 \\
\hline & Range & & $75-105$ & $75-103$ & $70-102$ & $70-105$ & $71-99$ \\
\hline & SE & & 5 & 5 & 5 & 6 & 5 \\
\hline & Mean (5) & FFA & 1.15 & 1.25 & 1.30 & 0.94 & 0.83 \\
\hline & Range & & $0.62-1.53$ & $0.61-1.91$ & $0.76-1.80$ & $0.50-1.34$ & $0.67-1.13$ \\
\hline & $\mathrm{SE}$ & & 0.15 & 0.19 & 0.19 & 0.13 & 0.08 \\
\hline & Mean (5) & Gly & 0.30 & 0.37 & 0.34 & 0.24 & 0.22 \\
\hline & Range & & $0.09-0.49$ & $0.12-0.65$ & $0.15-0.58$ & $0.14-0.40$ & $0.10-0.39$ \\
\hline & $\mathrm{SE}$ & & 0.07 & 0.08 & 0.07 & 0.05 & 0.05 \\
\hline & Mean (5) & IRI & 57 & 46 & 52 & 59 & 41 \\
\hline & Range & & $24-89$ & $24-83$ & $34-83$ & $25-83$ & $18-65$ \\
\hline & SE & & 13 & 10 & 9 & 9 & 8 \\
\hline & Mean (3) & $\mathrm{GH}$ & 8 & 7 & 6 & 9 & 10 \\
\hline & Range & & $3-12$ & $3-10$ & $3-8$ & $5-17$ & $5-18$ \\
\hline & $\mathrm{SE}$ & & 2 & 2 & 1 & 3 & 3 \\
\hline
\end{tabular}

* Number of samples for each time period.

$\ddagger$ Glu $(\mathrm{mg} / 100 \mathrm{ml})$, FFA $(\mu \mathrm{Eq} / \mathrm{ml})$, Gly $(\mu \mathrm{moles} / \mathrm{ml})$, IRI $(\mu \mathrm{U} / \mathrm{ml}), \mathrm{GH}(\mathrm{m} \mu \mathrm{g} / \mathrm{ml})$.

$\S$ Dose of glucose administered during infusion period.

in regulating lipolysis both on a short and more longterm basis. The sensitivity of this control mechanism to small differences in available glucose appears remarkable, since a significant reduction in lipolysis was maintained throughout a $24 \mathrm{hr}$ period, during which time the total caloric intake of the animal was limited to approximately $10 \mathrm{~g}$ of infused glucose. In addition, the mechanism appears to be operative over a rather narrow range of glucose levels, the effective range lying between 0.5 and $0.64 \mathrm{mg} / \mathrm{kg}$ per min. ${ }^{2}$ The change in lipolysis

' We have estimated that the concentration of glucose in the carotid arterial blood was raised by approximately 6-10 $\mathrm{mg} / 100 \mathrm{ml}$ (during infusion of glucose at a rate of $0.6 \mathrm{mg} /$ $\mathrm{kg}$ per $\mathrm{min}$ ). This estimate is based upon an assumed flow to the brain of $50 \mathrm{ml} / \mathrm{min}$ per $100 \mathrm{~g}$ of brain (19). The lower value is obtained if complete mixing of the two carotid flows in the circle of Willis is assumed, while the higher value represents the expected change if no mixing occurred before the blood reached a glucose-sensitive site. Since doses in this range did not significantly raise the concentration of glucose in central venous plasma during infusion by either route, it would appear that the brain and peripheral tissues were utilizing glucose at rates exceeding the infusion rate. The glucose consumption of the baboon brain has not been measured in these experiments. Estimates in humans are in noted with glucose infusions in this dose range was not associated with a consistent change in serum insulin, although in general a gradual fall in insulin was noted during the infusion periods. These data suggest that the reduction in lipolysis was not mediated by an acute change in the concentration of insulin reaching the adipose tissue. It is possible that glucose administered per carotid artery might have activated a vagal mechanism (23) for insulin secretion ${ }^{8}$ which was not detected in

the range of $110-145 \mathrm{~g} / 24 \mathrm{hr}$ after a brief fast $(20,21)$, while Owen, Morgan, Kemp, Sullivan, Herrera, and Cahill (22) obtained a value of $24 \mathrm{~g} / 24 \mathrm{hr}$ in subjects fasted for long periods. If we extrapolated to the baboon on the basis of brain mass, our animals would have glucose utilizations in brain of about $1.7 \mathrm{mg} / \mathrm{kg}$ per min after a short fast, or, if our baboons behaved as long-term fasted humans, the rate would be about $0.4 \mathrm{mg} / \mathrm{kg}$ per $\mathrm{min}$. These estimates suggest that the dose of glucose giving differential effects upon lipolysis ranged from 30 to $100 \%$ of the glucose consumption of the brain depending upon the state of adaptation to fasting in the animal.

3he apparent stability of peripheral blood glucose during intracarotid infusion of glucose is at variance with several published reports. Zunz and La Barre, using dogs (24), and Sakata, Hayano, and Sloviter, working with rabbits (25), 


\begin{tabular}{|c|c|c|c|c|c|c|c|}
\hline \multicolumn{2}{|c|}{$\begin{array}{l}\text { Intracarotid glucose } \\
\text { infusion }\end{array}$} & & \multicolumn{4}{|c|}{ Intravenous glucose infusion } & \multirow{2}{*}{$\frac{\text { Recovery }}{270}$} \\
\hline 90 & 120 & & 150 & 180 & 210 & 240 & \\
\hline 85 & 82 & & 81 & 80 & 79 & 77 & 77 \\
\hline $70-98$ & $70-96$ & & $69-91$ & $69-91$ & $65-87$ & $65-86$ & $65-85$ \\
\hline 5 & 5 & & 4 & 4 & 4 & 4 & 3 \\
\hline 0.92 & 0.93 & & 1.03 & 0.97 & 1.02 & 1.02 & 1.04 \\
\hline $0.61-1.30$ & $0.60-1.52$ & & $0.70-1.31$ & $0.73-1.11$ & $0.81-1.30$ & $0.84-1.23$ & $0.81-1.41$ \\
\hline 0.13 & 0.14 & & 0.10 & 0.06 & 0.10 & 0.07 & 0.10 \\
\hline 0.27 & 0.25 & & 0.28 & 0.24 & 0.26 & 0.25 & 0.26 \\
\hline $0.12-0.40$ & $0.10-0.46$ & & $0.15-0.40$ & $0.12-0.31$ & $0.14-0.42$ & $0.16-0.37$ & $0.16-0.38$ \\
\hline 0.05 & 0.05 & & 0.05 & 0.04 & 0.05 & 0.04 & 0.04 \\
\hline 32 & 32 & & 28 & 34 & 25 & 29 & 19 \\
\hline $16-50$ & $19-69$ & & $19-45$ & $23-47$ & $21-33$ & $20-38$ & $13-31$ \\
\hline 6 & 8 & & 5 & 4 & 2 & 3 & 3 \\
\hline 9 & 9 & . & 6 & 7 & 7 & 7 & 6 \\
\hline $5-13$ & $4-14$ & & $4-8$ & $4-11$ & $5-10$ & 5-11 & $3-9$ \\
\hline 2 & 2 & & 1 & 2 & 1 & 2 & 1 \\
\hline
\end{tabular}

the peripheral circulation but acted within the liver. In order for such a sequence to reduce circulating FFA and glycerol, but not glucose, insulin would have to markedly accelerate hepatic uptake of the two lipolytic products while not inhibiting hepatic glucose production. To date, such an effect of insulin has not been demonstrated. In addition, we have previously reported similar effects of glucose administered intravenously upon lipolysis in insulin-dependent diabetic human subjects who were unable to secrete additional insulin (13). However, as emphasized by Cahill, Herrera, Morgan, Soeldner, Steinke, Levy, Reichard, and Kipnis (26), insulin undoubtedly plays a role in the regulation of lipolysis. In the studies cited with diabetics, for instance, it was necessary to regulate their metabolism with long-

have previously noted a fall in peripheral glucose during administration of glucose to the central nervous system. The mechanism for such a change was not determined, but the possibility was raised that central glucose receptors acted through the vagus to increase insulin secretion. Our studies differ in several respects from these previous investigations. In addition to the species differences, the doses of glucose we have used are much smaller than those previously reported. acting insulin before responses to acute changes in glucose could be elicited. With the possible exception of prostaglandins (27), insulin is the only physiological factor which by itself can directly reduce the rate of lipolysis in adipose tissue. Therefore, a steady rate of lipolysis must be viewed as an equilibrium wherein the prevailing level of insulin activity is just balanced by the sum of activities of lipolytic factors. Increasing or decreasing the activity of either insulin or lipolytic stimulators then would change the rate of lipolysis. In our studies, the concentration of insulin in peripheral blood was unchanged or diminished, and we would postulate that glucose acted within the central nervous system to decrease the activity of a tonically active lipolytic system in the presence of a constant or diminishing antilipolytic effect of insulin.

$\mathrm{GH}$ was assayed as one example of a centrally controlled potential regulator of lipolysis. The circulating level of $\mathrm{GH}$ did not change in response to glucose in our studies. In fact, $\mathrm{GH}$ never rose significantly with long-term fasting in the baboon, a finding which casts doubt upon its postulated role in the lipolysis of fasting. Our experience with GH also did not support the sug- 
TABLE IV

Short-Term Infusion Studies: Dose of Glucose

\begin{tabular}{|c|c|c|c|c|c|c|c|}
\hline \multirow[b]{2}{*}{ Time in minutes. } & & & \multicolumn{3}{|c|}{ Saline control } & \multicolumn{2}{|c|}{$\begin{array}{l}\text { Intravenous glucose } \\
\text { infusion }\end{array}$} \\
\hline & - & $\ldots \ldots \ldots \ldots$ & -30 & -15 & 0 & 30 & 60 \\
\hline \multirow{9}{*}{$\begin{array}{c}\text { Four studies in three animals, } \\
0.76-0.83 \mathrm{mg} / \mathrm{kg} \text { per } \min \S\end{array}$} & Mean $(4)^{*}$ & Glut & 83 & 82 & 81 & 84 & 83 \\
\hline & Range & & $76-92$ & $75-92$ & $74-90$ & $72-92$ & $73-97$ \\
\hline & SE & & 3 & 3 & 3 & 4 & 5 \\
\hline & Mean (4) & FFA & 0.76 & 1.00 & 0.86 & 0.79 & 0.75 \\
\hline & Range & & $0.84-1.09$ & $0.81-1.22$ & $0.69-1.13$ & $0.60-1.03$ & $0.61-1.08$ \\
\hline & SE & & 0.21 & 0.08 & 0.08 & 0.08 & 0.10 \\
\hline & Mean (4) & IRI & 24 & 44 & 27 & 30 & 29 \\
\hline & Range & & $13-31$ & $10-67$ & $18-35$ & $14-40$ & $9-42$ \\
\hline & SE & & 3 & 11 & 3 & 5 & 6 \\
\hline
\end{tabular}

* Number of samples for each time period.

‡ Glu $(\mathrm{mg} / 100 \mathrm{ml})$, FFA $[\mu \mathrm{Eq} / \mathrm{ml})$, Gly $(\mu \mathrm{moles} / \mathrm{ml})$, IRI $(\mu \mathrm{U} / \mathrm{ml}), \mathrm{GH}(\mathrm{m} \mu \mathrm{g} / \mathrm{ml})$.

$\S$ Dose of glucose administered during infusion period.

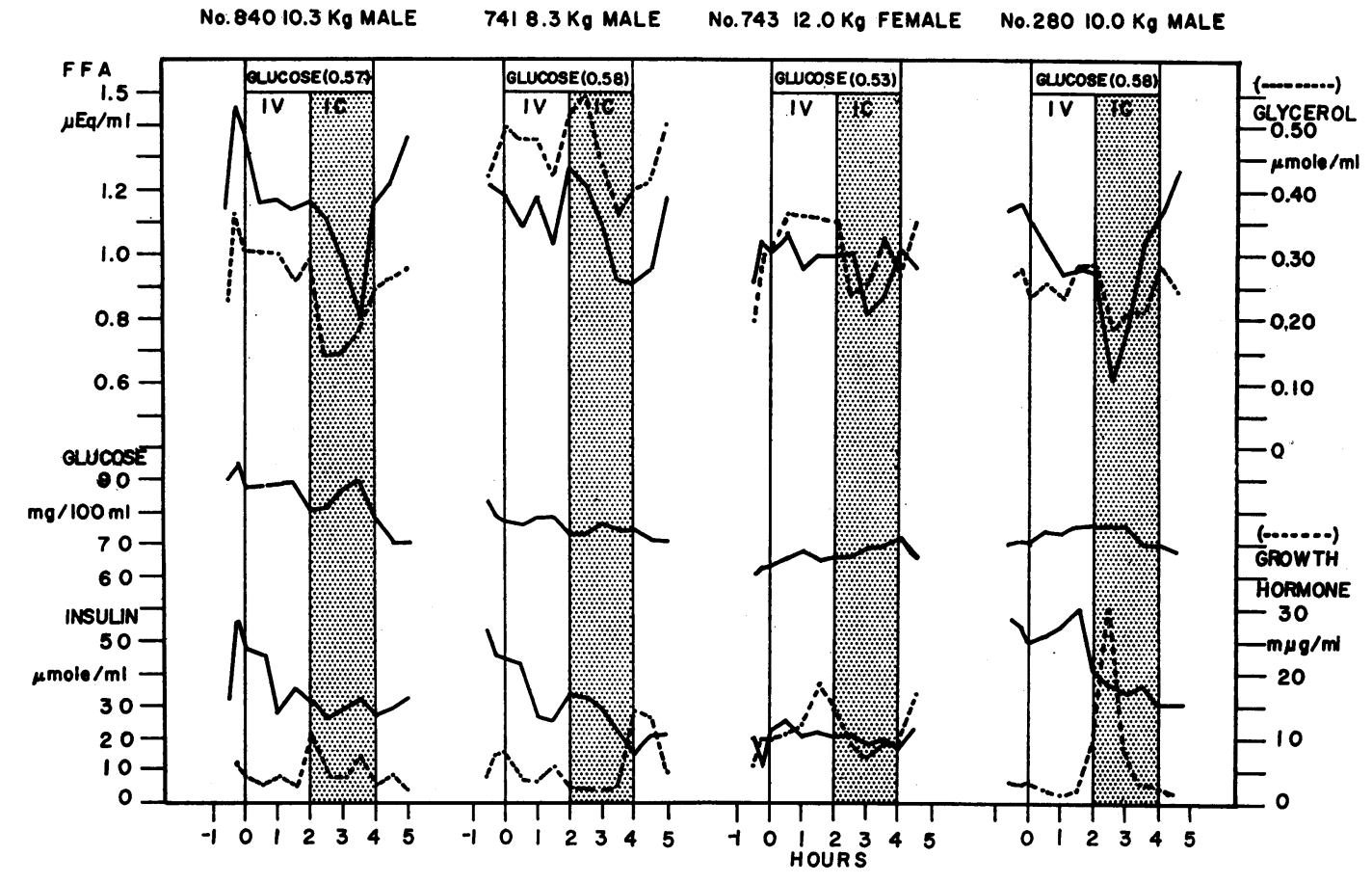

Figure 3 Short-term studies in four animals showing a differential fall in FFA and glycerol during infusion of glucose into the carotid artery. These studies illustrate the animal to animal variation in timing of responses to IC glucose. The doses of glucose are listed in parenthesis as milligrams/kilogram per minute. Consistent changes in glucose, insulin, and GH were not obtained during either infusion period. GH occasionally displayed random abrupt increases in concentration. 


\begin{tabular}{|c|c|c|c|c|c|c|c|}
\hline & \multicolumn{2}{|c|}{$\begin{array}{l}\text { Intravenous glucose } \\
\text { infusion }\end{array}$} & \multicolumn{4}{|c|}{ Intracarotid glucose infusion } & \multirow{2}{*}{$\frac{\text { Recovery }}{270}$} \\
\hline & 90 & 120 & 150 & 180 & 210 & 240 & \\
\hline & 89 & 82 & 85 & 82 & 80 & 80 & 82 \\
\hline & $82-98$ & $75-89$ & 73-95 & $70-89$ & 72-92 & 71-94 & $71-94$ \\
\hline & 3 & 3 & 5 & 4 & 4 & 4 & 4 \\
\hline & 0.80 & 0.76 & 0.93 & 0.79 & 0.86 & 0.86 & 0.91 \\
\hline • & $0.59-1.03$ & $0.61-0.89$ & $0.78-1.12$ & $0.54-1.02$ & $0.66-1.04$ & $0.70-1.20$ & $0.73-1.11$ \\
\hline & 0.09 & 0.05 & 0.07 & 0.09 & 0.08 & 0.10 & 0.07 \\
\hline & 31 & 23 & 40 & 23 & 22 & 24 & 23 \\
\hline & $14-49$ & $10-36$ & $13-68$ & $10-34$ & $14-31$ & $8-36$ & 9-28 \\
\hline & 6 & 6 & 10 & 6 & 3 & 6 & 4 \\
\hline
\end{tabular}

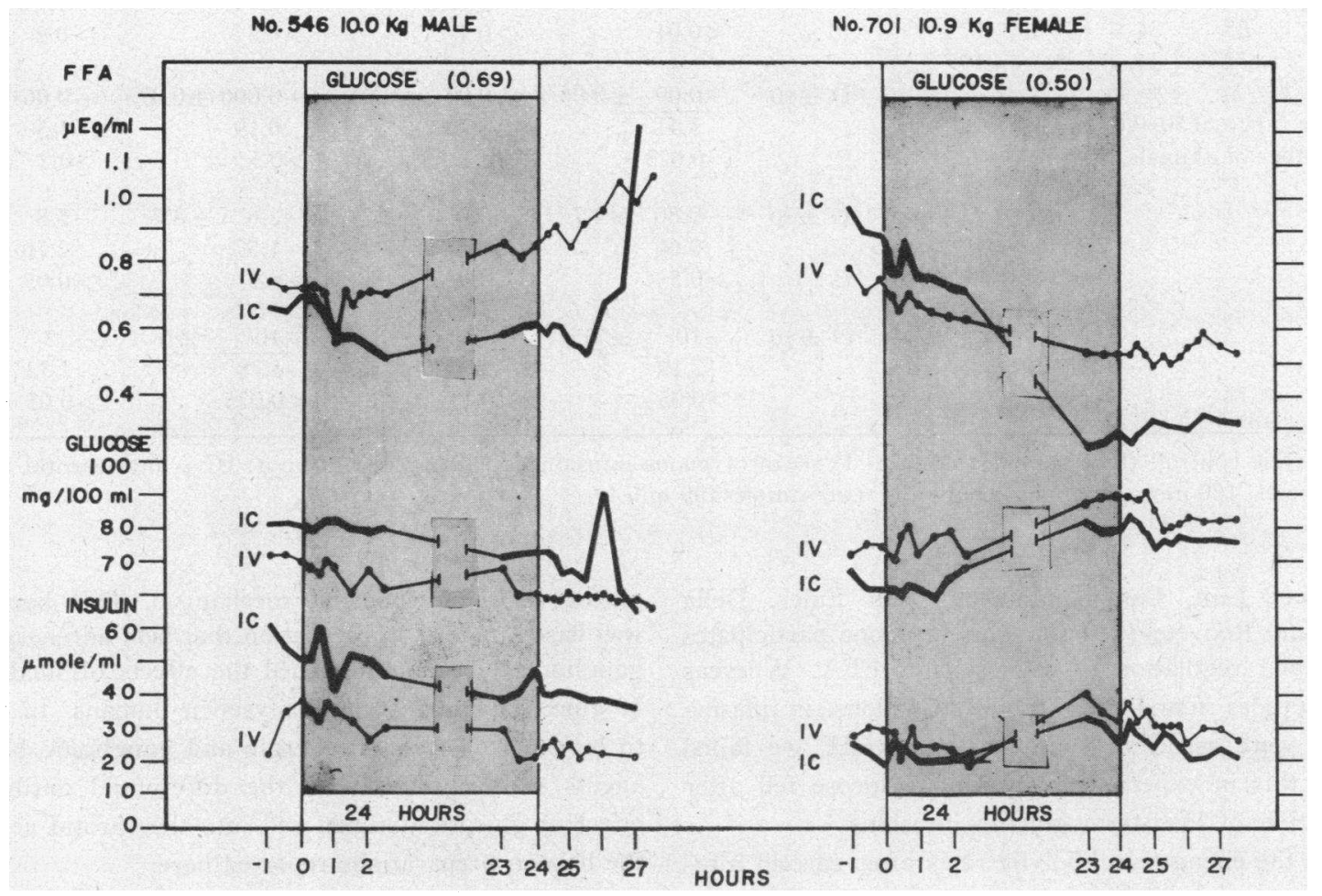

FIGURE 4 Long-term infusion in two animals. The baboons were fasted $20 \mathrm{hr}$ before study. In animal No. 546 , glucose was first infused intravenously at the indicated dose $(0.96 \mathrm{mg} / \mathrm{kg}$ per $\min$ ) for $24 \mathrm{hr}$. The animal was then restudied under the same conditions 1 wk later with infusion of glucose at the same rate into the carotid artery. In animal No. 701, the sequence of studies was reversed. In both animals, the concentration of FFA is relatively lower after intracarotid delivery of glucose. The total doses of glucose received over $24 \mathrm{hr}$ by the two animals were 10 and $8 \mathrm{~g}$, or 40 and 36 cal respectively. 
TABLE V

Test of Significance for Mean Difference ( $\bar{D})$ between Infusion Periods for Paired Comparisons in Individual Animals

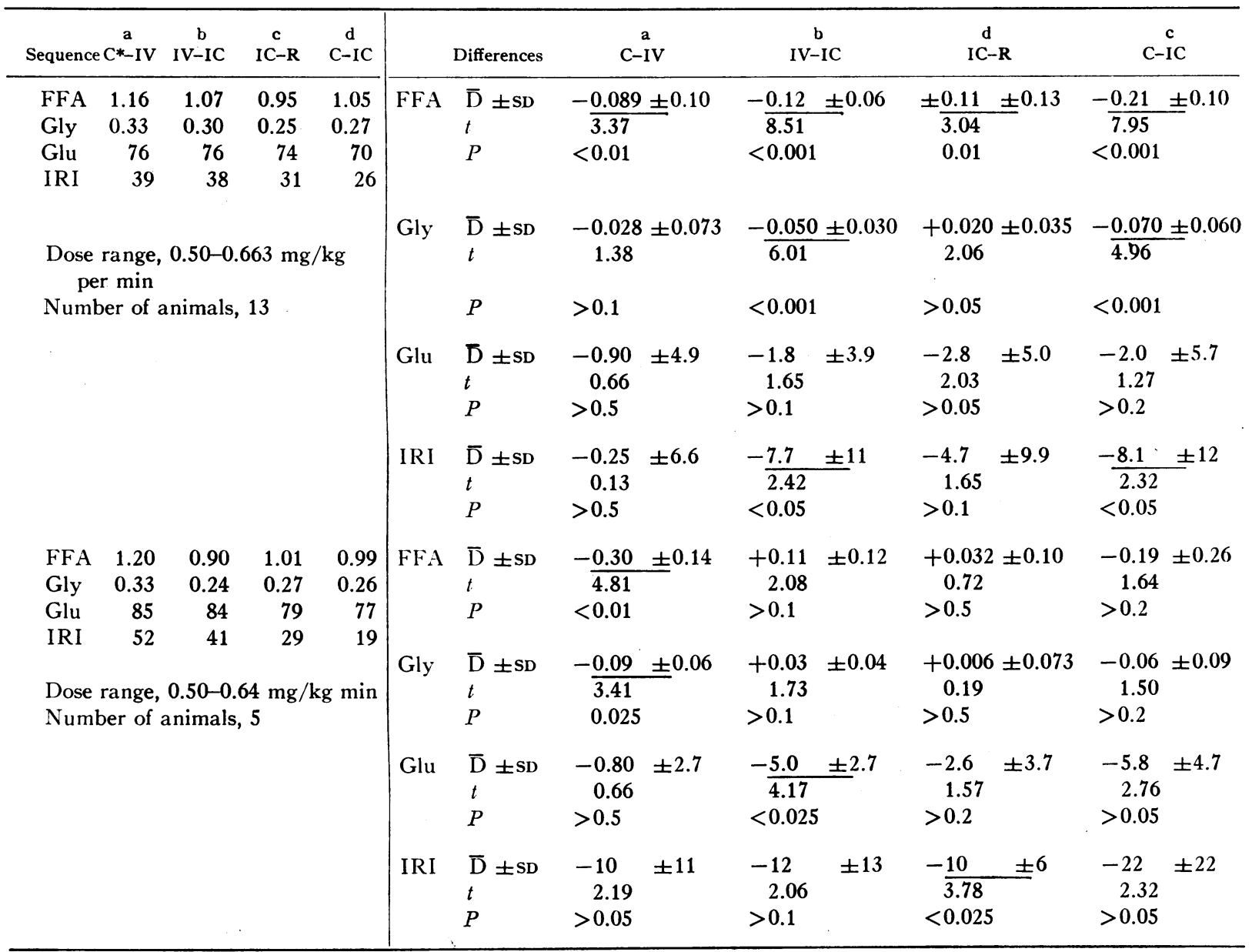

* $\mathrm{C}$ = saline control, three samples, $30 \mathrm{~min}$; IV = intravenous infusion, four samples, $120 \mathrm{~min}$; IC = intracarotid infusion four samples, $120 \mathrm{~min} ; \mathrm{R}=$ recovery period, two samples, $60 \mathrm{~min}$.

gestion of Luft, Cerasi, Madison, Von Euler, Della Cassa, and Roovete (28) that this hormone participates in the fine regulation of glucose and FFA. Whereas these authors found that small reductions in plasma glucose were associated with a rise in $\mathrm{GH}$, we failed to note this in experiments in which glucose fell after termination of long-term glucose infusions.

Since the changes in lipolytic rates after carotid infusion of glucose noted in the present study appear to occur independently of insulin or GH, the effect of glucose was apparently mediated by another mechanism. We have previously proposed that a change in the tonic activity of the sympathetic nervous system induced by glucose is the responsible mechanism. This hypothesis was based upon the observation that beta-adrenergic and ganglionic blockade abolished the effects of small doses of glucose upon fasting lipolysis in humans. In studies to be reported, beta-adrenergic and ganglionic blocking agents similarly abolished the differential antilipolytic effect of glucose administered into the carotid artery in the baboon preparations reported here.

Presently available information does not permit localization of the glucose-sensitive area beyond stating that it lies within the area of the internal carotid circulation. As a working hypothesis, we have suggested the hypothalamus as a likely site for a center concerned 
with substrate balance, since it would permit integration of such a system with other areas possessing related activities such as appetite regulation, temperature regulation, control of hypophyseal hormone secretion, and integration of autonomic responses. The observation that the fasting animals were often calmed during the period of carotid infusion perhaps lends some credence to the thought that the hypothalamus is involved, since affective behavior is in part controlled in this region (29). Present knowledge of the characteristics of the ventro-median (VM) and lateral hypothalamic centers (30) suggests that they might qualify as the postulated control system for fasting lipolysis. Thus the VM nucleus is probably glucose sensitive, and its effect is inhibitory when it is stimulated by glucose (31). The center which is inhibited, the lateral center, is tonically active in fasting animals, and these centers are thought to be part of the adrenergic pathways in the limbic system (32). On this basis, we would suggest that the lateral center might be tonically active to stimulate both feeding behavior and the lipolysis of fasting, and that both activities might be influenced by the prevailing level of glucose acting as an inhibitory chemical signal through the VM nucleus.

\section{ACKNOWLEDGMENT}

This investigation was supported in part by research grants AM 10866 and NB 06622 and training grant AM 5331 from the U. S. Public Health Service.

\section{REFERENCES}

1. Dole, V. P. 1956. A relationship between non-esterified fatty acids in plasma and the metabolism of glucose. J. Clin. Invest. 35: 150.

2. Gordon, R. S., Jr., and A. Cherkes. 1956. Unesterified fatty acid in human blood plasma. J. Clin. Invest. 35: 206.

3. Fröberg, S., S.-O. Liljedahl, and L. Orö. 1964. Free fatty acids of plasma during insulin induced hypoglycemia in dog. The effect of adrenalectomy and treatment with reserpine, azamethonium, and nicotinic acid. Acid Med. Scand. 176: 685.

4. Cantu, R. C., B. L. Wise, A. Goldfien, K. S. Gullixson, N. Fisher, and W. F. Ganong. 1963. Neural pathways mediating the increase in adrenal medullary secretion: produced by hypoglycemia. Proc. Soc. Exp. Biol. Med. 114: 10

5. Steinberg, D., and M. Vaughan. 1963. Metabolic and hormonal regulation of the mobilization of fatty acids from adipose tissue. Proc. 5th Int. Congr. Biochem. 7: 162.

6. Randle, P. J., P. B. Garland, C. N. Hales, and E. A. Newsholme. 1963. The glucose fatty-acid cycle. Its role in insulin sensitivity and the metabolic disturbances of diabetes mellitus. Lancet. I: 785 .

7. Jeanrenaud, B., and A. E. Renold. 1959. Studies on rat adipose tissue in vitro. IV. Metabolic patterns produced in rat adipose tissue by varying insulin and glucose con- centrations independently from each other. J. Biol. Chem. 234: 3082.

8. Jungas, R. L., and E. G. Ball. 1963. Studies on the metabolism of adipose tissue. XII. The effects of insulin and epinephrine on free fatty acid and glycerol production in the presence and absence of glucose. Biochemistry. 2: 383.

9. Roth, J., S. M. Glick, R. S. Yalow, and S. A. Berson. 1963. Hypoglycemia : a potent stimulus to secretion of growth hormone. Science. 140: 987.

10. Unger, R. H., A. M. Eisentraut, and L. L. Madison. 1963. The effects of total starvation upon the levels of circulating glucagon and insulin in man. J. Clin. Invest. 42: 1031.

11. LeFebvre, P. 1966. The physiological effect of glucagon on fat mobilisation. Diabetologia. 2: 130.

12. Goodner, C. J., and W. A. Tustison. 1964. Autonomic mediation of the effect of raised arterial glucose upon free fatty acids. Science. 146: 770.

13. Goodner, C. J., W. A. Tustison, M. B. Davidson, P.-C. Chu, and M. J. Conway. 1967. Studies of substrate regulation in fasting. I. Evidence for central regulation of lipolysis by plasma glucose mediated by the sympathetic nervous system. Diabetes. 16: 576.

14. Fredrickson, D. S., K. Ono, and L. L. Davis. 1963. Lipolytic activity of postheparin plasma in hyperglyceridemia. J. Lipid Res. 4: 24.

15. Dole, V. P., and H. Meinertz. 1960. Microdetermination of long chain fatty acids in plasma and tissues. J. Biol. Chem. 235: 2595.

16. Wieland, O. 1957. Eine enzymatische Methode zur Bestimmung von Glycerin. Biochem. Z. 329: 313.

17. Morgan, C. R., and A. Lazarow. 1963. Immunoassay of insulin: two antibody system: plasma insulin levels of normal, subdiabetic, and diabetic rats. Diabetes. 12: 115.

18. Schalch, D. S., and M. L. Parker. 1964. A sensitive double antibody immunoassay for human growth hormone in plasma. Nature (London). 203: 1141.

19. McHenry, L. C., Jr. 1966. Cerebral blood flow. N. Engl. J. Med. 274: 82.

20. Kety, S. S. 1957. The general metabolism of the brain in vivo. In The Metabolism of the Nervous System. D. Richter, editor. Proceedings of the 2nd International Neurochemical Symposium, Aarhus, Denmark, 1956. Pergamon Press, New York. 221.

21. Reinmuth, O. M., P. Scheinberg, and B. Bourne. 1965 Total cerebral blood flow and metabolism. Arch. Neurol. 12: 49.

22. Owen, O. E., A. P. Morgan, H. G. Kemp, J. M. Sullivan, M. G. Herrera, and G. F. Cahill, Jr. 1967. Brain metabolism during fasting. J. Clin. Invest. 46: 1589.

23. Frohman, L. A., E. Z. Ezdinli, and R. Javid. 1967. Effect of vagotomy and vagal stimulation on insulin secretion. Diabetes. 16: 443.

24. Zunz, E., and J. La Barre. 1927. Sur la sensibilité des centres nerveux supérieurs à l'hyperglycémie provoquée par injection de dextrose. C. R. Seances Soc. Biol. 96: 1400.

25. Sakata, K., S. Hayano, and H. A. Sloviter. 1963. Effect on blood glucose concentration of changes in availability of glucose to the brain. Amer. J. Physiol. 204: 1127.

26. Cahill, G. F., Jr., M. G. Herrera, A. P. Morgan, J. S. Soeldner, J. Steinke, P. L. Levy, G. A. Reichard, Jr., 
and D. M. Kipnis. 1966. Hormone-fuel interrelationships during fasting. J. Clin. Invest. 45: 1751.

27. Steinberg, D., M. Vaugan, P. J. Nestle, and S. Bergström. 1963. Effects of prostaglandin $E$ opposing those of catecholamines on blood pressure and on triglyceride breakdown in adipose tissue. Biochem. Pharmacol. 12: 764.

28. Luft, R., E. Cerasi, L. L. Madison, U. S. von Euler, L. Della Casa, and A. Roovete. 1966. Effect of a small decrease in blood-glucose on plasma growth hormone and urinary excretion of catecholamines in man. Lancet. 2: 254.

29. Grossman, S. P. 1966. The VMH: a center for affective reactions, satiety, or both? Physiol. Behav. 1: 1 .
30. De Groot, J. 1967. Organization of hypothalamic feeding mechanisms. In Handbook of Physiology, Section 6, Volume I, Alimentary canal. American Physiological Society, Washington, D. C. 239.

31. Anand, B. K. 1967. Central chemosensitive mechanisms related to feeding. In Handbook of Physiology, Section 6, Volume I, Alimentary canal. American Physiological Society, Washington, D. C. 249.

32. Grossman, S. P. 1967. Neuropharmacology of central mechanisms contributing to control of food and water intake. In Handbook of Physiology, Section 6, Volume I, Alimentary canal. American Physiological Society, Washington, D. C. 287. 